Metallophysics and Advanced Technologies

Металофіз. новітні технол.

Metallofiz. Noveishie Tekhnol.

2019, vol. 41, No. 10, pp. 1291-1301

https://doi.org/10.15407/mfint.41.10.1291

Reprints available directly from the publisher
(C) 2019 G. V. Kurdyumov Institute for Metal Physics, National Academy of Sciences of Ukraine Published by license under the G. V. Kurdyumov Institute for Metal PhysicsN.A.S. of Ukraine Publishers imprint. Printed in Ukraine.

PACS numbers: 61.72.jj, 62.40.+i, 66.30.J-, 68.35.Dv, 71.15.-m, 81.40.Np

\title{
Mechanical Spectroscopy Studies of Hydrogen Mobility in Titanium Doped Iron Alloy
}

\author{
S. M. Teus and V. G. Gavriljuk
}

\author{
G.V.Kurdyumov Institute for Metal Physics, N.A.S. of Ukraine, \\ 36 Academician Vernadsky Blvd., \\ UA-03142 Kyiv, Ukraine
}

Mobility of hydrogen atoms in the $\beta$-phase of titanium alloys doped with iron is studied by means of mechanical spectroscopy. As shown, the hydrogen dissolution in the $\beta$-phase results in appearance of the Snoek-like relaxation at temperatures about $80 \mathrm{~K}$. The $a b$ initio atomic calculations are used to analyse atomic complexes responsible for the relaxation. The results suggest an affinity of hydrogen atom to iron in titanium and a responsible of $s-\mathrm{H}$ complexes ( $s$-substitutional atom) with the symmetry lower than the cubic one for Snoek-like relaxation. The obtained activation energy of hydrogen migration in the $\beta$-phase assumes that such phase could serve as a pathway of hydrogen to the $\alpha$-phase where the hydride could form.

Key words: titanium, hydrogen, mechanical spectroscopy, first principles calculations, Snoek relaxation, hydrogen embrittlement.

Рухливість атомів водню в $\beta$-фазі сплавів титану із додаванням заліза досліджено методом механічної спектроскопії. Показано, що розчинення водню в $\beta$-фазі супроводжується появою Снукоподібної релаксації при температурах в околі 80 К. Ab initio атомні розрахунки використано для аналізу атомних комплексів, що відповідають за релаксацію. Результати демонструють схильність атому водню до заліза в титані та відповідальність $s-$ Н комплексів ( $s$ - атом заміщення) із симетрією, нижчою за кубічну, за Снукоподібну релаксацію. Отримане значення ентальпії активації міграції водню в $\beta$-фазі передбачає, що дана фаза відіграє роль шляхопроводів для атомів водню до $\alpha$-фази, в якій можуть утворюватися гідриди.

Corresponding author: Sergiy Myronovych Teus

E-mail: teus@imp.kiev.ua

Citation: S. M. Teus and V. G. Gavriljuk, Mechanical Spectroscopy Studies of Hydrogen Mobility in Titanium Doped Iron Alloy, Metallofiz. Noveishie Tekhnol., 41, No. 10: 1291-1301 (2019), DOI: 10.15407/mfint.41.10.1291. 
Ключові слова: титан, водень, механічна спектроскопія, розрахунки із перших принципів, релаксація Снука, водневе окрихчення.

Подвижность атомов водорода в $\beta$-фазе сплавов титана с добавлением железа исследована методом механической спектроскопии. Показано, что растворение водорода в $\beta$-фазе сопровождается появлением Снукоподобной релаксации при температурах в окрестности 80 К. Ab initio атомные расчёты использовались для анализа атомных комплексов, ответственных за релаксацию. Результаты демонстрируют склонность атомов водорода к железу в титане и ответственность $s-\mathrm{H}$ комплексов ( $s-$ атом замещения) с симметрией, ниже кубической, за Снукоподобную релаксацию. Полученное значение энтальпии активации миграции водорода в $\beta$ фазе предполагает, что данная фаза играет роль путепроводов для атомов водорода к $\alpha$-фазе, в которой могут формироваться гидриды.

Ключевые слова: титан, водород, механическая спектроскопия, расчёты из первых принципов, релаксация Снука, водородное охрупчивание.

(Received July 2, 2019)

\section{INTRODUCTION}

Titanium-based alloys represent a special class of construction materials which are actively used in the industry and possess important characteristics such as strength and weight, e.g. [1-6]. At the same time, similarly to other metallic alloys, they also suffer from the negative hydrogen effects. Mechanisms of their hydrogen embrittlement are the topic of extensive studies [7-13]. In general, titanium alloys are categorized based on the phase composition, e.g. $\alpha, \beta, \alpha+\beta[6]$. However, in relation to their hydrogen-caused brittleness, a more appropriate classification should be the following: (i) hydride-forming alloys and (ii) those stable to hydride formation. Taking into account that hydrides are relatively brittle phases, they are frequently considered as a main reason for the brittle fracture of initially ductile alloys [8-11]. e.g., the $\mathrm{X}$-ray diffraction studies of the titanium alloy $\beta$-21S after its gaseous hydrogen charging revealed that the hydrogen-induced cracking is directly caused by formation of the tetragonal hydride phase [7].

In case of titanium alloys where the hydrides are not formed, a mechanism of embrittlement is more complicated. The $\beta$-titanium alloys are typical example where the hydride phase is not formed. Nevertheless, hydrogen changes their mechanical behaviour from the ductile with the coalescence of microvoids to the brittle one with cleavage fracture, see e.g. [13].

A number of hypotheses were proposed to explain the hydrogen brittleness of $\beta$-titanium alloys. Among them, the most frequently used are the decohesion mechanism [14-16] and that of hydrogen enhanced localized plasticity, HELP [17-19]. 
A conclusion about the hydrogen-caused decohesion is mainly based on the experimental data were after certain critical hydrogen concentration the ductile to brittle transition occurs (e.g. [16]). From the other hand, the HELP model considers the hydrogen-caused shielding of elastic stresses around the dislocations, which increases their velocity and decreases the distance between dislocations in the planar dislocation ensembles [20]. An important role of dislocations in the crack initiation step and the effect of hydrogen atmospheres on dislocation properties are completely ignored in the decohesion model but confirmed in a number of experimental studies, e.g. [17, 21, 22].

As demonstrated in [23], the continuum mechanics approach to interaction between hydrogen atoms and dislocations ignores the nature of hydrogen as a chemical element and the hydrogen-caused elastic shielding of the interaction between dislocations cannot be the only reason for hydrogen brittleness. The electron concept of HELP has been proposed in [23-25] of which the essence is the hydrogenincreased metallic character of interatomic bonding, which changes dislocation properties. The validity of the electron approach for hydrogen embrittlement of $\beta$-titanium alloys has been shown earlier in [26].

An important step in any model of hydrogen brittleness is the rate of hydrogen migration to the places of its potential accumulation. As shown in [27] for titanium alloys, the brittleness appears if the hydrogen clouds follow the dislocations during plastic deformation. This experimental study confirmed the importance of hydrogen atoms mobility in the attempts to predict the changes in mechanical behaviour of materials.

The aim of the present research was to study the hydrogen atoms mobility in the titanium $\beta$-phase, a type of crystal lattice defects responsible for the Snoek-like relaxation and the role of the b.c.c. phase in the hydrogen brittleness of $\alpha+\beta$ titanium alloys.

\section{METHODS}

The titanium alloys with 2 and $4 \%$ mass of Fe were presented for studies by Dr. Savvakin, G. V. Kurdyumov Institute for Metal Physics. A technology of their preparation is described in [26]. The samples of $1 \times 1$ $\mathrm{mm}^{2}$ in square and $50 \mathrm{~mm}$ in the length were made for measurements using spark cutting followed by the grinding and polishing of their surface.

Hydrogen charging has been carried out in the aerated $1 \mathrm{~N} \cdot \mathrm{H}_{2} \mathrm{SO}_{4}$ solution containing $100 \mathrm{mg} / \mathrm{l} \mathrm{NaAsO}$ to prevent the recombination of hydrogen atoms. The current density and charging time were 50 $\mathrm{mA} / \mathrm{cm}^{2}$ and 72 hours, respectively. To prevent the hydrogen degassing, the samples were stored in liquid nitrogen after charging. 
The temperature dependent internal friction (TDIF) was used to study hydrogen mobility in these alloys. The measurements were carried out using an automated inverted pendulum operated at different frequencies within the temperature range of $77 \mathrm{~K}$ to $580 \mathrm{~K}$ with the heating rate of about $1.5 \mathrm{~K} / \mathrm{min}$.

To study the hydrogen location in the b.c.c. titanium doped iron, the first principles atomic calculations have been performed using $\mathrm{Ti}_{53} \mathrm{Fe}_{1} \mathrm{H}_{1}$ simulation cell. These calculations are based on the KohnSham (KS) density functional theory, DFT [28, 29]. The WIEN2k program package [30] and the full-potential-linearized-augmented plane wave method, FLAPW were used to solve the KS equations. The calculation of the exchange-correlation potential was carried out using the generalized gradient approximation in the parameters of Perdew, Burke and Ernzernhoff [31] where the gradient terms of electron density are added to the exchange-correlation energy and its potential. Brillouin zone integration is performed with a $12 \times 12 \times 12 k$-point mesh. The magnitude of the largest vector $G$ in the Fourier expansion was equal to 24 . The force convergence was set to $0.1 \mathrm{mRy} / \mathrm{a} . \mathrm{u}$. with the interatomic forces between the atoms smaller than $2 \mathrm{mRy} / \mathrm{a} . \mathrm{u}$. for the accurate determination of atomic positions. To find the equilibrium lattice constant, the Murnaghan's equation of state [32] was used by fitting the total energy versus the unit cell volume.

To determine the solution enthalpy of hydrogen atoms in the $\beta$ titanium lattice, the following equation was used:

$$
\Delta H_{\text {sol }}=E_{\text {tot }}\left(\mathrm{Ti}_{n} \mathrm{H}\right)-E_{\text {tot }}(\mathrm{Ti})-\frac{1}{2} E_{\mathrm{H}_{2}},
$$

where $E_{\text {tot }}(X)$ are total energies of corresponding cells and $E_{\mathrm{H}_{2}}$ is a total energy of the hydrogen molecule. The zero-point energy correction terms were calculated within the harmonic approximation. The force constants were obtained from $a b$ initio calculations according to direct method [33, 34]. An additional approximation is that the force constants concerned with the displacements of titanium atoms from their equilibrium positions could be equal to zero as the mass of the titanium atom is significantly higher than that of the hydrogen atom. After the diagonalization of the Hessian matrix, the normal mode frequencies of hydrogen atoms were determined and the zero-point energy have been calculated by summing up the zero-point vibration energies: $E_{\mathrm{ZPE}}=$ $=(1 / 2) \sum_{i}\left(h v_{i}\right)$, where $v_{i}$ is a real normal mode frequency.

\section{RESULTS}

The express X-ray diffraction analysis revealed that the both alloys consist of two phases: $\alpha$-h.c.p. and $\beta$-b.c.c. The existence of the b.c.c. 
phase is definitely caused by the addition of iron as a well known $\beta$ stabilizer. The hydrogen charging makes the structure more complicated because of titanium hydride formation, which results from the limited hydrogen solubility in the $\alpha$-phase.

Such a complicated multi-phase structure is reflected in the profile of temperature dependent internal friction measurements of the both alloys and represented in Fig. 1, $a, b$. The advantage of the internal
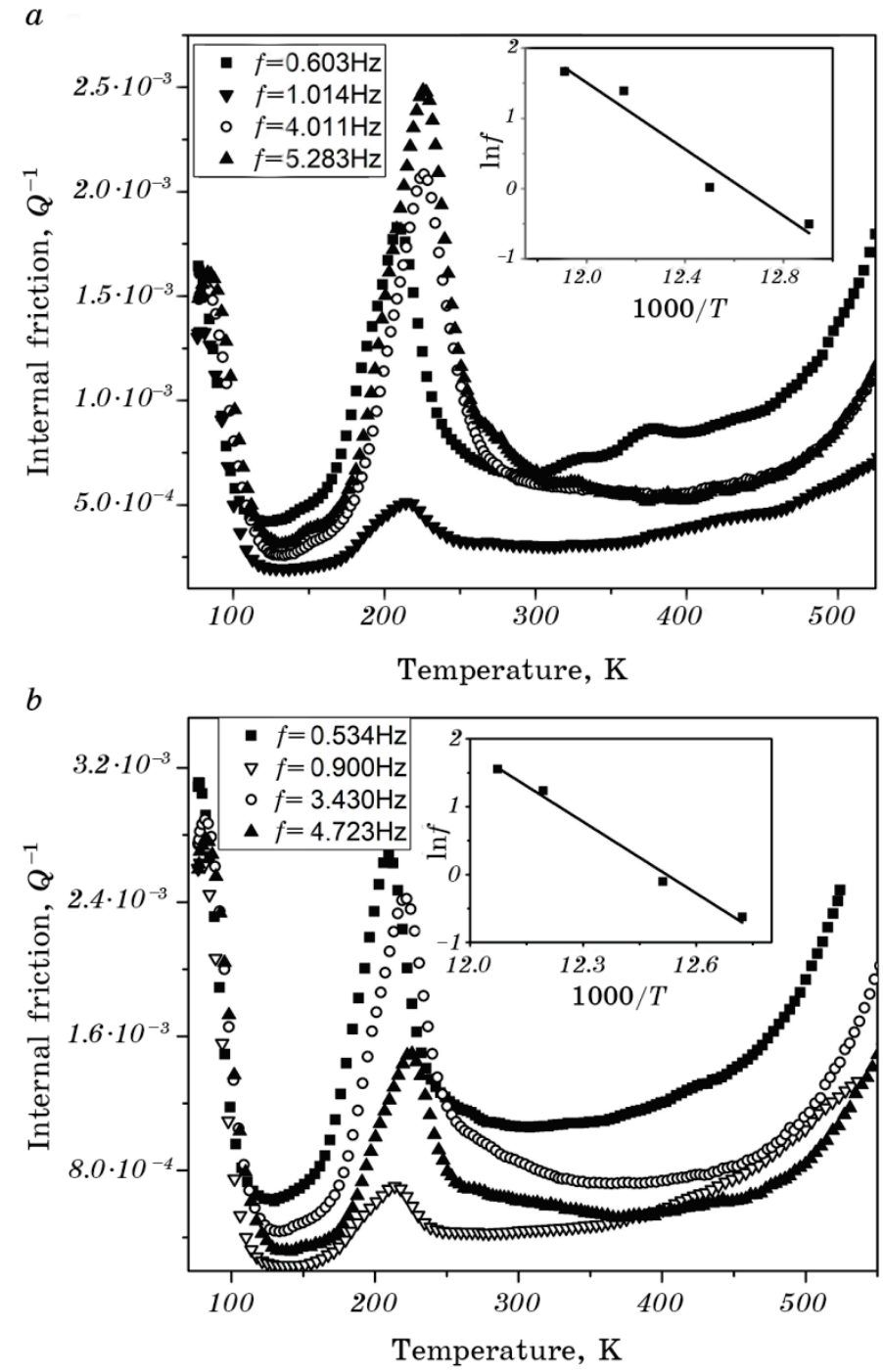

Fig. 1. Temperature-dependent internal friction of hydrogen-charged titanium alloys: $\mathrm{Ti}-2 \%$ wt. $\mathrm{Fe}(a)$; Ti-4\% wt. Fe $(b)$. The treatment of experimental data in the Arrhenius co-ordinates is shown in the inserts to each Figure. 
friction (IF) in comparison with other methods for studies of hydrogen mobility, e.g., hydrogen permeation, is that the hydrogen behaviour in each phase can be distinguished. Therefore, characteristics of hydrogen migration can be precisely determined, whereas the permeation technique gives only average characteristics of hydrogen mobility.

As it is seen in Fig. 1, the internal friction spectra could be separated into three parts: (i) the low temperature sharp peak at about $80 \mathrm{~K}$, (ii) the broad peak in the temperature range of $150 \mathrm{~K}$ to $300 \mathrm{~K}$ and (iii) some peaks traces at temperatures between $325 \mathrm{~K}$ and $400 \mathrm{~K}$. The comparison with the results of a similar study on the hydrogen-charged $\beta$ titanium alloy, as presented in [26], allows to conclude that the peak at about $80 \mathrm{~K}$ is related with hydrogen migration in the $\beta$-phase, whereas the high temperature peaks at $T>325 \mathrm{~K}$ are connected with transient processes, i.e. hydrogen degassing and/or its redistribution over the crystal lattice deep traps. Their very weak intensity means that such processes practically do not occur. The broad peak in between $150 \mathrm{~K}$ and $300 \mathrm{~K}$ can be related with hydrogen in the $\alpha$-phase and titanium hydrides. The further discussion will be concentrated on the hydrogen behaviour in the b.c.c. phase, i.e. only the low temperature peak is analysed.

The variation in the oscillation frequency shifts the temperature position of the $80 \mathrm{~K}$ peak, which indicates on its relaxation nature and can be related to the Snoek-like relaxation caused by the hydrogen atom diffusion jumps in the $\beta$-phase. Owing to the limited temperature range of experimental technique, the low temperature peak could not be recorded completely. Nevertheless, knowing the peak shape equation, the fitting procedure could be used to determine its temperature position. After the IF background subtraction, the peaks profiles have been fitted using the broadened Debye equation and the lognormal distribution of activation parameters, as described in [35]. For each frequency, a single peak approximation has been used during the fitting process.

Taking into account the thermally activated character of the Snoeklike relaxation, $\tau=\tau_{0} \exp \left(H_{m} / k T\right)$, where $H_{m}$ is the enthalpy for migration, $\tau$ is the relaxation time, $k$ is Boltzmann constant and $T$ is temperature, the treatment of experimental data in the Arrhenius coordinates allows to determine the activation enthalpy of hydrogen migration.

The obtained results are presented in the inserts in Fig. 1, $a, b$. The results of data processing together with other peak characteristics like its amplitude and the area under peak are summarized in Table 1. As seen, the variation in the iron content does not change the activation parameter for hydrogen migration within the limits of error, but affects the total area under the peak, as well as its total intensity.

To get more information about the hydrogen state in the $\beta$-phase, 
TABLE 1. Characteristics of hydrogen caused low temperature peak in studied alloys. $H_{m}$ is the activation enthalpy of hydrogen migration. Amplitude and peak area are taken as the average values.

\begin{tabular}{c|c|c|c}
\hline Alloy & $H_{m}, \mathrm{eV}$ & Amplitude & Peak area \\
\hline $\mathrm{Ti}-2 \%$ wt. Fe & $0.20 \pm 0.03$ & 0.00128 & 0.00335 \\
$\mathrm{Ti}-4 \%$ wt. Fe & $0.22 \pm 0.02$ & 0.00257 & 0.00676 \\
\hline
\end{tabular}

the first principles calculations have been performed with particular attention to hydrogen location in the b.c.c. titanium doped with the iron atoms. Figure 2 demonstrates the total cohesion energy of $\mathrm{Ti}_{54} \mathrm{H}_{1}$ atomic configuration as a function of cell volume if the hydrogen atom is located in the tetrahedral or octahedral interstitial positions. The cohesion energy is determined using the following expression:

$$
E_{\text {coh }}=E_{\text {tot }}-\sum_{i=1}^{N} E_{\mathrm{i}}^{\text {at }}
$$

where $E_{\text {tot }}$ is the total energy of the crystal structure, $E_{\mathrm{i}}^{\text {at }}$ is the energy of isolated atom constituting the calculated structure. The summation is performed over the all atoms in the calculated cell.

As seen from Fig. 2, the cohesion energy in the state of thermodynamical equilibrium of the calculated cell with the hydrogen atom in the octahedral interstitial position has a lower value. A similar conclusion follows from the comparison of hydrogen solution energy in the

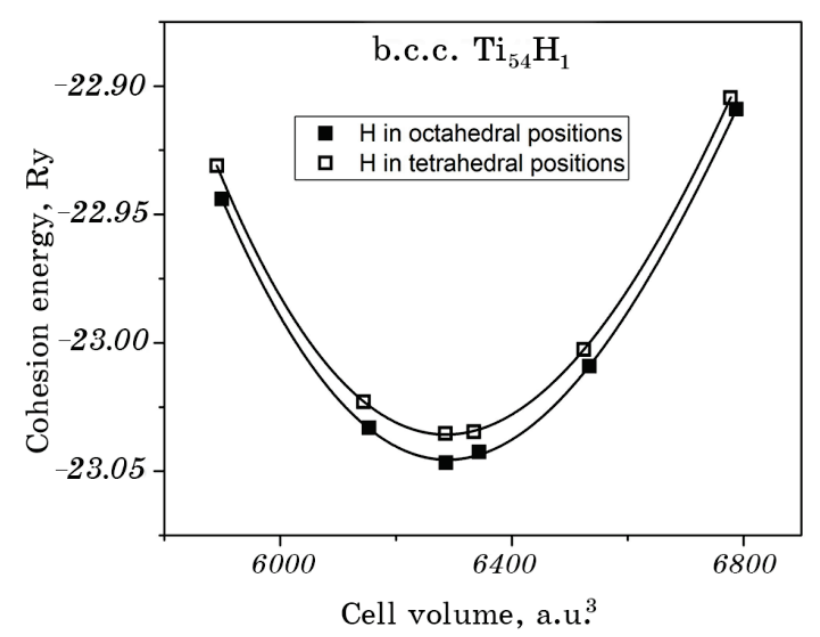

Fig. 2. Cohesion energy as a function of cell volume for hydrogen location in octahedral or tetrahedral interstitial positions in $\beta$-titanium. 
both interstitial sites. Taking into account the zero-point energy corrections, the hydrogen solution energy in the tetrahedral site is equal to $-0.47 \mathrm{eV}$ whereas for the octahedral site it is equal to $-0.69 \mathrm{eV}$. The experimentally measured enthalpy of hydrogen solution in the b.c.c. Ti is equal to $-0.62 \mathrm{eV}$ [36].

The hydrogen location in the b.c.c. titanium in relation to the iron atoms has been calculated using $\mathrm{Ti}_{53} \mathrm{Fe}_{1} \mathrm{H}_{1}$ simulation cell. The calculations of cohesion energy show that if the $\mathrm{Fe}-\mathrm{H}$ nearest-neighbour distance is of $2.5214 \AA$, the energy is equal to $-23.133 \mathrm{Ry}$, whereas for the $\mathrm{Fe}-\mathrm{H}$ nearest-neighbour distance of $3.4731 \AA$ the energy is equal to $-23.125 \mathrm{Ry}$. Both values are lower in comparison with the cohesion energy of hydrogen in the substitutional-free b.c.c. titanium $(-23.047$ Ry), which clearly shows the hydrogen preferential location in the vicinity of the iron atoms.

\section{DISCUSSION}

The results of internal friction measurements coupled with the first principles simulation allows to analyse the hydrogen mobility in the $\beta$ phase of titanium alloy and the role of iron atoms in the relaxation process. The IF spectra presented in Fig. 1 reveal a complex behaviour which results from the multi-phase structure of hydrogenated alloys. Nevertheless, the low temperature part of the spectrum can be clearly separated and related with hydrogen migration in the $\beta$-phase.

Snoek-like relaxation is caused by the stress-induced reorientation of hydrogen complexes with substitutional atoms. To analyse such complexes, the knowledge about hydrogen location in the b.c.c. lattice is necessary. The results of first principles atomic calculations allow to conclude that hydrogen atoms in the b.c.c. Ti-H structure occupy octahedral interstitial sites (see Fig. 2). As shown earlier, see [26], at much higher hydrogen concentrations up to $\mathrm{Ti}_{2} \mathrm{H}$ tetrahedral interstitial positions are more favourable. To explain this discrepancy, the hydrogen concentration in combination with the possibilities of atomic relaxation should be analysed.

Let us consider the $\mathrm{Ti}_{2} \mathrm{H}$ structure. The wide solubility range of hydrogen in the b.c.c. titanium allows such a concentration to be observed in the experiment. Nevertheless, if hydrogen is located in the octahedral sites, because of symmetry, the local relaxation of atomic positions cannot be realized. From the other hand, if hydrogen is located in a tetrahedral site, tetrahedral interstitial positions can be favourable because of a larger free volume and on account that their symmetry allows a local atomic relaxation. For the case of $\mathrm{Ti}_{54} \mathrm{H}_{1}$ structure, because of a smaller hydrogen contents, there are no such limitations in the local atomic displacements around the hydrogen atom, which makes the cohesion energy of hydrogen in octahedral positions 
lower in comparison with the tetrahedral ones. This is also confirmed by the estimated hydrogen solubility which is in a good agreement with the experimental data [36].

Knowing the favourable interstitial sites occupied by hydrogen in the $\beta$-titanium, its location in relation to the iron atom position in the $\mathrm{Ti}_{53} \mathrm{Fe}_{1} \mathrm{H}_{1}$ structure can be analysed. As follows from the results of simulations, the hydrogen atoms tend to be neighbours of the iron ones in comparison with their location near titanium atoms. Moreover, with increasing distance from the iron atom, the cohesion energy tends to decrease.

Taking into account a relatively low concentration of substitutional elements in the studied alloys, the observed Snoek-like relaxation in the $\beta$-phase can originate from the diffusion jumps of hydrogen atoms located in octahedral interstitial positions where the octahedral configuration contains an iron atom, creating thereby the $s-\mathrm{H}$ complexes ( $s$-substitutional element, i.e. the iron). Such a complex adds the additional deviation from the cubic symmetry created by hydrogen atom in the octahedral sites, and the reorientation of such defect under the action of external force enhances probability of relaxation.

As follows from the analysis of data presented in Table 1, the increase in the Fe content does not change the activation enthalpy for hydrogen migration in the $\beta$-phase but increases the amplitude of Snoek-like relaxation and the area under relaxation peak. Taking into account that the relaxation strength is proportional to the concentration of hydrogen atoms in the solid solution, the following conclusions can be made that (i) the iron increases hydrogen solubility in the titanium $\beta$-phase and (ii) within the range of concentration studied, the addition of iron does not change the configuration of complexes responsible for relaxation but increases their quantity. It is surprising that the change in the iron concentration from $2 \%$ wt. to $4 \%$ wt. increases the Snoek-like relaxation amplitude by two times. It can be a sign that namely the $\mathrm{Fe}-\mathrm{H}$ complexes preferentially contribute to the Snoek-like relaxation.

The obtained data of activation enthalpy for hydrogen migration can be compared with that obtained in the titanium alloy $\mathrm{Ti}-10 \mathrm{~V}-2 \mathrm{Fe}-3 \mathrm{Al}$ prepared using the same technique [26]. In the present study, it is by about of $0.06 \mathrm{eV}$ smaller. It could be explained by the presence of $\mathrm{V}$ and/or $\mathrm{Al}$ in $\mathrm{Ti}$ 10-2-3 alloy where at least vanadium as a hydrideforming element has a strong affinity to hydrogen and reduces its mobility due to stronger bonding states.

In case of the studied $\alpha+\beta$ alloys, a high mobility of hydrogen atoms in the $\beta$-phase will be served as pathways for hydrogen migration into the $\alpha$-phase, where because of limited hydrogen solubility the Ti hydride precipitates, which in combination with its brittle behaviour will increase the level of brittleness. 


\section{CONCLUSIONS}

1. Mechanical spectroscopy allows one to study the hydrogen mobility in the $\beta$-phase of the $\alpha+\beta$ titanium alloys and determine the activation enthalpy of hydrogen atom migration, which is of about $0.21 \mathrm{eV}$.

2. Using ab initio atomic calculations it is shown that the $s-\mathrm{H}$ complexes, where $s$ is substitutional iron atom, are responsible for Snoek-like relaxation that is observed at about $80 \mathrm{~K}$.

3. An increase in the iron concentration increases the hydrogen solubility in the $\beta$-phase but does not change the configuration of atomic complexes responsible for the relaxation.

\section{REFERENCES}

1. M. Ribeiro, M. Moreira, and J. Ferreira, J. Mater. Processing Technol., 143: 458 (2003).

2. M. Rahman, Z. Wang, and Y. Wong, JSME International Journal Series C, 49: 11 (2006).

3. P. Arrazola, A. Garay, L. M. Iriarte, M. Armendia, S. Marya, and F. Le Maitre, J. Mater. Process. Technol., 209: 2223 (2009).

4. M. J. Donachie, Titanium: a Technical Guide (USA, ASM International: 2000).

5. G. Lutjering and J. C. Williams, Titanium (Germany: Springer Verlag: 2007).

6. C. Veiga, J. P. Davim, and A. J. R. Loureiro, Rev.Adv. Mater. Sci., 32: 133 (2012).

7. D. Eliezer, E. Tal-Gutelmacher, C. E. Cross, and Th. Boellinghaus, Mater. Sci. Eng. A, 421 Nos. 1-2: 200 (2006).

8. D. P. Williams and H. G. Nelson, Metal. Trans., 3, No. 8: 2107 (1972).

9. D. A. Meyn, Metal. Trans., 3, No. 8: 2302 (1972).

10. H. G. Nelson, Metal. Trans. A, 7, No. 5: 621 (1976).

11. R. Dutton, K. Nuttall, M. P. Puls, and L. A. Simpson, Metal. Trans. A, 8, No. 10: 1553 (1977).

12. L. A. Simpson and M. P. Puls, Metal. Trans. A, 10, No. 8: 1093 (1979).

13. D. A. Hardwick and D. G. Ulmer, Hydrogen Effects in Metals

(Eds. A. W. Thompson and N. R. Moody) (PA, Warrendale: TMS: 1996), p. 735.

14. R. A. Oriani and P. H. Josephic, Acta Metal., 25, No. 9: 979 (1977).

15. R. A. Oriani, Corrosion, 43, No. 7: 390 (1987).

16. D. F. Teter, I. M. Robertson, and H. K. Birnbaum, Acta Mater., 49, No. 20: 4313 (2001).

17. P. J. Ferreira, I. M. Robertson, and H. K. Birnbaum, Acta Mater., 46, No. 5: 1749 (1998).

18. G. M. Bond, I. M. Robertson, and H. K. Birnbaum, Acta. Metall., 35, No 9: 2289 (1987).

19. D. S. Shih, I. M. Robertson, and H. K. Birnbaum, Acta Metal., 36, No. 1: 111 (1988).

20. H. K. Birnbaum and P. Sofronis, Mater. Sci. Eng. A., 176: 191 (1994).

21. S. D. Pu and S. W. Ooi, Materials Science and Engineering: A, 761: 138059 (2019). 
22. G. A. Young and J. R. Scully, Corrosion, 50, No. 12: 919 (1994).

23. V. G. Gavriljuk, B. D. Shanina, V. N. Syvanyuk, and S. M. Teus, J. Appl. Phys., 108: 083723 (2010).

24. S. M. Teus, V. N. Shyvanyuk, B. D. Shanina, and V. G. Gavriljuk, phys. status solidi (a), 204: 4249 (2007).

25. V. G. Gavriljuk, B. D. Shanina, V. N. Shyvanyuk, and S. M. Teus, Corros. Rev., 31: 33 (2013).

26. S. M. Teus, D. G. Savvakin, O. M. Ivasishin, and V. G. Gavriljuk, Int. J. Hydr. Energy., 42: 2424 (2017).

27. R. M. Gabidullin, B. A. Kolachev, and P. D. Drozdov, Problemy Prochnosti [Problems of Strength], 12: 36 (1971) (in Russian).

28. P. Hohenberg and W. Kohn, Phys. Rev., 136: B864 (1964).

29. W. Kohn and L. J. Sham, Phys. Rev., 140: A1133 (1965).

30. P. Blaha, K. Schwarz, G. K. H. Madsen, D. Kvasnicka, and J. Luitz, WIEN2k, An Augmented Plane Wave + Local Orbitals Program for Calculating Crystal Properties (Austria, Wien: Techn. Universität Wien: 2001).

31. J. P. Perdew, S. Burke, and M. Ernzernhoff, Phys. Rev. Lett., 77: 3865 (1996).

32. F. D. Murnaghan, Proc. Natl. Acad. Sci., 30, Iss. 9: 244 (1944).

33. K. Kunc and R. M. Martin, Phys. Rev. Lett., 48: 406 (1982).

34. M. T. Yin and M. L. Cohen, Phys. Rev. B, 26: 3259 (1982).

35. A. S. Nowick and B. S. Berry, Anelastic Relaxation in Crystalline Solids (New York: Academic Press: 1972).

36. Y. Fukai, The Metal-Hydrogen System (Springer Series in Materials Science, 2nd Ed.) (Berlin: Springer: 2005). 